•综述・

\title{
国家公园生态系统完整性评价研究进展
}

\author{
代云川1,2\#薛亚东 ${ }^{1,2 \#}$ 张云毅 $^{3}$ 李迪强 $1,2 *$ \\ 1 (中国林业科学研究院森林生态环境与保护研究所, 北京 100091) \\ 2 (国家林草局生物多样性保护重点实验室，北京 100091) \\ 3 (国家林草局野生动植物保护与自然保护区管理司, 北京 100084)
}

\begin{abstract}
摘要：建立国家公园可促进生态环境和生物多样性的保护, 而国家公园生态系统完整性评价对于维持生态系统平 衡、生态系统健康、生物多样性以及典型生态系统的完整性具有重要意义。本文介绍了生物完整性指数评价体系 (Index of Biotic Integrity, IBI)、三级法评估框架(Three Level Approach, TLA)和生态系统完整性评估框架(Ecosystem Integrity Assessment Framework, EIAF)三种国家公园生态系统完整性评价方法, 其中生物完整性指数评价体系基 于高强度的野外调查和室内实验分析, 虽然花费大、耗时长以及生物鉴定专业性要求较高, 但评价结果准确可靠; 三级法评估框架分为三个级别, 即远程型评价(Remote Assessment)、快速型评价(Rapid Assessment)和密集型评价 (Intensive Assessment), 在评价独立且较为复杂的生态系统完整性时具有极大的灵活性; 生态系统完整性评估框 架吸取了生物完整性指数评价体系和三级法评估框架的优点, 扩充了评价体系的指标, 优化了生态系统完整性评 价计分统计方法, 是目前最为成熟的评价方法之一。同时, 本文也探讨了目前国家公园生态系统完整性评价研究 中存在的一些问题, 如评价指标不全、评价形式单一和评价方法主观性较强等。作者指出, 国家公园生态系统完 整性的研究需要注重自然一经济一社会的结合与统一, 加强社会经济可持续发展与人类健康等方面的研究, 挖掘外 来入侵物种与生态环境之间的关系, 继续寻找能够反映生态系统完整性状态和变化趋势的新的指示物种, 进而制 定统一标准的评价方法体系。
\end{abstract}

关键词：国家公园；生态系统完整性；生物多样性；评价；指标

\section{Summary comments on assessment methods of ecosystem integrity for national parks}

Yunchuan Dai ${ }^{1,2 \sharp}$, Yadong Xue ${ }^{1,2 \sharp}$, Yunyi Zhang ${ }^{3}$, Diqiang $\mathrm{Li}^{1,2^{*}}$

1 Institute of Forest Ecology, Environment and Protection, Chinese Academy of Forestry, Beijing 100091

2 Key Laboratory of Biodiversity Conservation, State Forestry and Grassland Administration, Beijing 100091

3 Department of Wildlife Conservation and Nature Reserve Management, State Forestry and Grassland Administration, Beijing 100084

\begin{abstract}
National parks are one of the foundations of global biodiversity conservation and help protect the ecological environment and biodiversity. Assessing ecosystem integrity in national parks can help understand ecosystem balance, health, and biodiversity status. We introduce three methods to assess ecosystem integrity of national parks: IBI (Index of Biotic Integrity), TLA (Three Level Approach) and EIAF (Ecosystem Integrity Assessment Framework), respectively. IBI relies on high intensity field survey and laboratory analysis. Albeit expensive, time consuming and requiring high level of biological expertise in identifying species, the results are accurate and reliable. TLA, including Remote Assessment, Rapid Assessment and Intensive Assessment, offers great flexibility to assess the integrity of complex ecosystems. EIAF combines the advantages of IBI and TLA, expands the use of indicator species and optimizes scoring statistics. Hence, EIAF is one the most sophisticated assessment methods of ecosystem integrity for national parks. We also discuss
\end{abstract}

收稿日期: 2018-05-15; 接受日期: 2018-08-20

基金项目: 国家重点研发计划(2017YFC0506405)和国家林业和草原局野生动物保护管理项目( 国家公园生态系统完整性评估体系研究)

\# 共同第一作者 Co-first authors

* 通讯作者 Author for correspondence. E-mail: lidq@caf.ac.cn 
some issues such as incomplete assessment indices, single assessment form and subjectivity of assessment methods in current studies. We propose that research on ecosystem integrity of national parks should combine the processes that join nature, economy and society. Such an interdisciplinary approach requires integrated research on sustainable socio-economic development and human health, and explore the relationship between invasive species and ecological environment. We also suggest the need to look for new indicator species that can reflect the state and change trend of ecosystem integrity and thus help develop a standardized assessment system for national parks.

Key words: national park; ecosystem integrity; biodiversity; assessment; index

自1872年世界上第一个国家公园在美国建立 以来, 国家公园在美洲、欧洲、亚洲、非洲以及大 洋洲迅速发展, 截至2017年底, 全世界已有200个 国家建立了 5,625 个符合国家公园( II 类)类型的保护 地(IUCN, 1993; 唐芳林, 2017)。国家公园作为世界 自然保护事业发展的产物, 是全球生物多样性保护 的基础(Gaston et al, 2006; Timko \& Satterfield, 2008)。建立国家公园能够促进生态环境和生物多样 性的保护, 对于维护典型生态系统的完整性具有重 要意义(Timko \& Satterfield, 2008; Timko \& Innes, 2009; 唐芳林, 2017)。然, 许多国家公园在运行和 管理的过程中面临诸多问题和挑战, 如管理有效性 缺失、保护目标难以实现、生物多样性和生态系统 完整性(ecosystem integrity)下降以及生态可持续性 发展遭受质疑等(Scott et al, 2001; Salafsky et al, 2002; Rodrigues et al, 2004; Abebe \& Bekele, 2018)。 为了发挥国家公园作用、体现国家公园建立的初衷 并消除公众的质疑, 对其地位、功能以及效益进行 全面评价是非常必要的(Hockings et al, 2000; Stolton, 2004; Troy \& Yolanda, 2017), 国家公园生态系 统完整性评价的概念正是在这一背景下提出的 (Dudley et al, 1999; Parrish et al, 2003; Stolton, 2004)。近年来, 以美国和加拿大为代表的国家已经 开展了许多相关的研究工作(Timko \& Innes, 2009; Ladin et al, 2016; Elisa et al, 2016; Schroeder et al, 2017), 如加拿大设立国家公园时特别强调 “典型 性”和“生态系统完整性”, 为保护和展示自然景观 和自然现象的杰出代表, 保护栖息地、野生生物和 生态系统多样性, 保持或者恢复国家公园的生态系 统完整性, 即保持生态系统健康完整, 使其生物多 样性和生态系统的结构、功能以及过程不受破坏。

我国国家顶层设计也充分考虑了国家公园与 生态系统完整性的关系, 一系列重要文件均明确提
出“建立国家公园体制，保护自然生态和自然文化 遗产的原真性与完整性”。本文通过对国家公园生 态系统完整性评价方法进行系统总结分析, 希望可 以对解答我国国家公园建设中遇到的问题如“应该 建在哪里”、“面积应该多大”、“环境变化和人为干 扰下能否仍然具有代表性”等有所帮助, 并为制定 国家公园建设遴选标准、区划方法、评价体系提供 参考。

\section{1 生态系统完整性的定义}

生态系统完整性是建立在生物完整性和生态 健康相关概念的基础之上，是生态系统评价当中的 一个重要概念(Harwell et al, 1999), 这一概念最早 由Leopold (1949)在一篇关于土地伦理学的文章中 提出。生态系统完整性评价是指评价一个生态系统 的结构、功能以及过程的完整性(Karr \& Dudley, 1981; Karr, 1981; Young \& Sanzone, 2002; Parrish et al, 2003)。同时, 生态系统完整性也表示一个生态系 统应该在相对的生态属性和时空尺度上不受损害, 生物群落保持一定的完整。在以往的研究中, 不同 学者对生态系统完整性的理解有所不同, 并从不同 尺度阐释了其定义(表1)，总体可归纳为：生态系统 完整性是生态系统物理、化学和生物完整性之和, 是与某一原始状态相比, 质量和状态没有遭受破坏 (张明阳等, 2005)。目前, 生态系统完整性已成为生 态系统管理的目标和价值所在。如加拿大国家公园 管理局指出生态系统完整性是国家公园管理的终 极目标，而生态系统管理则是用于达成这一目标的 过程(Parks Canada Agency, 2005)。

\section{2 国家公园生态系统完整性评价内涵}

对于国家公园的定义目前公认的是指把大面 积的自然或接近自然的区域保护起来，以保护大尺 度的生态过程及其相关的物种和生态系统特性 
表1 不同尺度上生态系统完整性的定义

Table 1 Definitions of ecosystem integrity from different scales

\begin{tabular}{|c|c|c|}
\hline 尺度 Scale & 定义 Definition & 参考文献 Reference \\
\hline $\begin{array}{l}\text { 生物群落 } \\
\text { Organism } \\
\text { community }\end{array}$ & $\begin{array}{l}\text { 生态系统完整性是支撑和维持生物群落平衡、完整以及适应的能力, 并且这个生物群落与所处 } \\
\text { 的自然生境一样, 具备物种构成、物种多样性以及功能组织等特点。 } \\
\text { Ecosystem integrity is the capability of supporting and maintaining a balanced, integrated, adaptive } \\
\text { community of organisms having a species composition and functional organization comparable to } \\
\text { that of the natural habitat of the region. }\end{array}$ & $\begin{array}{l}\text { Karr \& Dudley, 1981; } \\
\text { Karr, } 1981\end{array}$ \\
\hline $\begin{array}{l}\text { 优势种 } \\
\text { Dominant species }\end{array}$ & $\begin{array}{l}\text { 当原生物种成为优势种并主宰整个生物群落时, 生态系统将表现出相对稳定和健康, 即为生态 } \\
\text { 系统完整性。 } \\
\text { When native species become dominant species and dominate the entire community, the ecosystem } \\
\text { exhibits relative stability and health, namely ecosystem integrity. }\end{array}$ & Noss, 1990 \\
\hline $\begin{array}{l}\text { 生态干扰 } \\
\text { Ecological } \\
\text { disruption }\end{array}$ & $\begin{array}{l}\text { 生态系统完整性是生态系统在特定地理区域的最优化状态, 在这种状态下, 生态系统具备区域 } \\
\text { 自然生境所应包含的全部本土生物多样性和生态学过程, 其生态系统结构、功能以及过程不受 } \\
\text { 人类威胁和损害, 生态系统均在自然变化范围之内并保持良性循环, 且本地物种处在能够持续 } \\
\text { 繁衍的种群水平上。 } \\
\text { Ecosystem integrity is defined as a state of ecosystem development that is optimized for its geo- } \\
\text { graphic location. In this state, the ecosystem with regional natural habitats contains all native biodi- } \\
\text { versity and ecological process, its ecosystem structure, function and process are not subject to human } \\
\text { threat or damage, ecosystem in the range of natural changes and maintain a virtuous circle, and na- } \\
\text { tive species are present at viable population levels. }\end{array}$ & Woodley, 1993 \\
\hline $\begin{array}{l}\text { 自组织过程 } \\
\text { Self-organization } \\
\text { process }\end{array}$ & $\begin{array}{l}\text { 当一个生态系统在不受人类干预的条件下能够继续维持正常的生态功能, 即使当环境遭受人 } \\
\text { 类干扰时, 其生态系统照常能够维持自组织和稳定的状态, 并有足够的能力来继续自组织的发 } \\
\text { 展, 这种自组织能力就叫生态系统完整性。 } \\
\text { Under the condition without the intervention of human, the ecosystem can continue to maintain the } \\
\text { normal ecological function, even when the environment is disturbed by human, the ecosystem is still } \\
\text { able to maintain its self-organization and stable state, and it has enough ability to continue the de- } \\
\text { velopment of self-organization, this kind of self-organization ability is called ecosystem integrity. }\end{array}$ & Müller, 1998 \\
\hline $\begin{array}{l}\text { 自然属性 } \\
\text { Natural quality }\end{array}$ & $\begin{array}{l}\text { 当一个生态系统具备与自然区域相同的属性特征, 包括丰富的原生物种和丰富的生物群落构 } \\
\text { 成, 即为生态系统完整性。 } \\
\text { When an ecosystem has the same attribute characteristics as the natural region, it includes the rich } \\
\text { native species and the composition of the biological community, namely ecosystem integrity. }\end{array}$ & $\begin{array}{l}\text { Parks Canada Agency, } \\
2005\end{array}$ \\
\hline
\end{tabular}

(IUCN，1993)。在我国《建立国家公园体制总体方

案》(http://www.gov.cn/zhengce/2017-09/26/content_ 5227713.htm)中则把国家公园定义为: 国家公园是 由国家批准设立并主导管理, 边界清晰, 以保护具 有国家代表性的大面积自然生态系统为主要目的, 实现自然资源科学保护和合理利用的特定陆地或 海洋区域。中国特色的国家公园建设的主要目的是 保护大面积的自然生态系统, 其首要功能是保护重 要自然生态系统的原真性、完整性，同时兼具科研、 教育、游悡等综合功能(彭杨靖等, 2018)。国家公园 生态系统完整性评价的主要内容是对国家公园生 态系统的结构、功能以及过程完整性进行评价, 判 断当前生态系统是否能够继续维持生态系统平衡、 生态系统健康以及生物多样性; 其评价的目的是保 护生态环境、生物多样性以及自然资源, 为管理部 门合理规划保护地和制定相应的保护政策提供依 据。国家公园生态系统完整性评价赋予了生态保护 价值、生态管理理念和生态系统恢复一定意义, 能 够解决生态环境保护和管理中遇到的若干问题, 如:
(1)在固定和客观尺度上评估生态系统完整性; (2)比 较同一生态系统各种事件的生态完整性; (3)识别和 选取优先保护区域; (4)生境质量与生物资源的动态 监测; (5)提供一个完整的综合指数来解释监测数据, 包括随时追踪生态系统完整性状况等。国家公园生 态系统完整性评价在生态保护中具有重大意义, 因 此有必要采用合理的方法来为其提供指导。

\section{3 国家公园生态系统完整性评价方法}

国家公园生态系统完整性评价旨在衡量一个 区域的生态系统完整性, 并结合某一特定生态系统 的结构、功能以及过程的特点对其进行标准化和可 重复化评估 (Fairweather，1991; Murtaugh，1996; Michael et al, 2011)。它通常采用多个指标对某一特 定生态系统的结构、功能以及过程进行描述和说明, 并结合统计学方法将不同类型的生态指标转化成 生态系统完整性指数来反映生态系统完整性状况 (Fairweather, 1991; Murtaugh, 1996; Michael et al, 2011)。Woodley (1993)提出了国家公园生态系统完 
整性监督和评价体系, 该体系由生物多样性、生态 系统过程和压力源三个部分组成。后来加拿大将此 体系作为国家公园生态系统完整性评价的标准方 法, 运用在对生物多样性和生态系统过程的保护中 (Parks Canada Agency, 2005)。目前, 国家公园生态 系统完整性评价方法主要是基于一些生态指标而 建立, 其中具代表性的有生物完整性指数评价体系 (Index of Biotic Integrity, IBI)、三级法评估框架 (Three Level Approach, TLA)和生态系统完整性评 估框架(Ecosystem Integrity Assessment Framework, EIAF) (Medeiros \& Torezan, 2013; Mahan et al, 2015)。

\section{1 评价指标选取原则}

生态系统完整性评价指标涉及物理、化学、生 物等多学科领域, 指标选取的合理性直接决定了评 价的准确性(Brewer \& Menzel, 2009)。由于不同生态 系统类型和不同生态尺度之间存在差异, 因此在建 立评价指标体系时首先要从当前生态系统实际情 况出发, 对比目前和过去的生态干扰类型, 选择具 备生态学意义并与重要的生态系统结构、功能以及 过程密切相关的指标, 同时这些指标能够对环境质 量的变化作出迅速反应并体现其变化机制(Franklin et al, 2002; Young \& Sanzone, 2002)。本文总结了国 家公园生态系统完整性的主要评估指标(表2), 并归 纳了指标选取的特点: (1)多尺度。通过景观指数来 解决多尺度指标选择问题; (2)历史性。对比当前和 过去的生态干扰类型选取指标; (3)实用性。选取指 标对科研工作者和决策者都具有实用性; (4)灵活 性。基于不同生态系统类型和规模来选取指标; (5) 度量性。可量化指标; (6)综合性。考虑生态系统结 构、功能以及过程, 把景观环境、生物条件、非生 物条件以及种群数量结合起来, 同时分析生物和非 生物之间的相互关系; (7)可重复性(Caniani，2016; Brown \& Williams, 2016; Troy \& Yolanda, 2017)。

\section{2 生物完整性指数评价体系}

生物完整性指数评价体系最早是由美国学者 Karr (1981)提出, 并以鱼类作为指示生物构建的评 估体系, 主要用于评价河流健康状况和湿地生态系 统健康(Karr \& Dudley, 1981)。发展至今, 生物完整 性指数评价体系已被广泛应用于河流、湖泊、沼泽、 海岸滩涂、池塘、水库等湿地的生态健康评价, 指 示生物类群也由鱼类扩展到底栖动物、着生藻类、 维管植物、两栖动物和鸟类等(Raab \& Bayley, 2012;
Chin et al, 2014; Li et al, 2015)。针对不同区域和研 究目的, 生物完整性指数评价体系衍生出了一些新 的评估方法，如底栖生物完整性指数(Benthic Index of Biotic Integrity, B-IBI) (Lawrence et al, 2011)、硅 藻生物完整性指数(Diatom Index of Biotic Integrity, D-IBI) (Tan et al, 2015)、鱼类群落生物完整性指数 (Fish Index of Biotic Integrity, F-IBI) (Casatti et al, 2009)、大型无脊椎动物完整性指数(Macroinvertebrate Index of Biotic Integrity, M-IBI) (Raburu et al, 2009; Lunde \& Resh, 2012)、浮游生物完整性指数 (Planktonic Index of Biotic Integrity, P-IBI)(Kane et al, 2009)以及生物完整性植被指数(Vegetation Index of Biotic Integrity, V-IBI) (Stapanian et al, 2013)。由 于生态系统健康直接影响到生态系统的结构、功能 以及过程的完整性, 生物完整性指数评价体系被运 用在了国家公园生态系统完整性评价中。Baron (2003)运用B-IBI指数来监测加拿大太平洋沿岸国 家公园保留地的流域生态系统完整性，对区域内19 条溪流进行采样, 样本包括浮游生物、禎翅目昆虫 以及毛翅目昆虫等, 结果表明流域内土地利用类型 的变化(land-use and land-cover change, LUCC)直接 影响生态系统完整性。因此, 土地利用类型的变化 可作为监测或评估湿地和流域生态系统完整性的 一个重要指标, 后来该指标作为核心指标之一被运 用到了三级法评估框架和生态系统完整性评估框 架中。

生物完整性指数评价体系基于高强度的野外 调查和室内实验分析, 虽花费大、耗时长, 生物鉴 定专业性要求较高, 但评价结果准确可靠, 是北美 国家公园生态系统监测和生态系统完整性评估常 用的方法之一(Baron, 2003)。值得注意的是，生物完 整性指数评价体系主要用于大尺度水生生态系统 完整性评价中, 因此采样范围需要考虑整个流域, 一旦采样范围不合理, 将直接影响到评估的准确 性。国家公园或保护区的边界有可能并未囊括整个 流域, 当使用生物完整性指数评价体系对水生生态 系统完整性进行评价时有必要对研究区域外的流 域范围进行采样, 以提高评价的准确性。

\section{3 三级法评估框架}

三级法评估框架由美国国家环境保护局(U. S. Environmental Protection Agency, UESPA)根据国家 公园和野生动物保护区的实际生态环境状况而研 
表2 国家公园生态系统完整性评价指标(Timko \& Satterfield, 2008; Timko \& Innes, 2009; Caniani, 2016; Brown \& Williams, 2016; Troy \& Yolanda, 2017)

Table 2 Summary of indices for ecosystem integrity assessment of national parks (Timko \& Satterfield, 2008; Timko \& Innes, 2009; Caniani, 2016; Brown \& Williams, 2016; Troy \& Yolanda, 2017)

\begin{tabular}{lll}
\hline 组成 Composition & 备选指标 Standby indices & 备选亚指标 Standby sub-indices \\
\hline 景观条件 & 景观结构 & 景观连接度、土地利用指数、缓冲指数、空间异质性、斑块大小、形状和分布、破碎度 \\
Landscape context & Landscape structure & $\begin{array}{l}\text { Landscape connectivity, land use index, buffer index, spatial heterogeneity, patch size, } \\
\text { shape and distribution, and fragmentation. }\end{array}$
\end{tabular}

景观状况

Landscape condition

生物条件生态系统与分区

Biological condition Ecosystem and zones

物种/种群

Species/population

种群动态测定

Population dynamic measure-

ment

演替/退化

Succession/degeneration

有机体状况

Organic condition

理化性质

空气质量和气候条件

Physiochemical

properties

Air quality and climatic conditions
土壤质量

Soil quality

水质

Water quality

土壤养分测定

Soil fertility determination

无机物和有机化学

Inorganic and

organic chemistry

化学参数

Chemical parameters

生态过程
Ecological
processes

水文地貌

Hydrological

features

能量流

Energy flow

物质流和有机碳循环

Material flow and

organic carbon cycle

地表径流、地下径流

Surface runoff,

underground runoff

动态结构特征

Dynamic structural feature

沉积物和物质输送

Sediment and material transport

自然干扰

频率、强度、持续时长

Natural disturbance
土地利用强度、土地利用类型、植被覆盖度

Land use intensity, land use type, and vegetation coverage.

群落范围、群落构成、群落动态、营养结构、物理结构

Community range, community composition, community dynamics, nutrition structure, physical structure.

物种分布范围、种群动态、种群结构、物种丰富度、原生物种、外来物种、形态变异 性、遗传多样性、栖息地适宜度

Species distribution, population dynamics, population structure, species richness, native species, alien species, morphological variability, genetic diversity, and habitat suitability.

指示物种的死亡率、出生率、生存力

The mortality, birth rate, and population viability of indicator species.

自然灾害干扰频率和程度、植被年龄群落分布

The frequency and degree of natural disaster interference, and the distribution of vegetation age group.

生理状态、疾病症状、疾病迹象

Physical condition, disease symptoms, and signs of illness.

基础气候数据、极端气候发生频率

Basic climatic data, and extreme climate occurrence frequency.

生物结皮、土壤侵蚀、土壤退化、土壤污染

Biological crust, soil erosion, soil degradation, and soil pollution.

水温、浑浊度、 $\mathrm{pH}$ 值、电导率、溶解性固体、悬浮性固体、总氮、总有机碳、溶解氧、 生化需氧量、化学需氧量、细菌总数、大肠菌群

Water temperature, turbidity, $\mathrm{pH}$, electrical conductivity, dissolved solids, suspended solids, total nitrogen, total organic carbon, dissolved oxygen, biochemical oxygen demand, chemical oxygen demand, total bacterial count, and coliform.

氮、磷、钲等养分含量

Content of nitrogen, phosphorus, calcium and other nutrients.

金属、有机化合物及其他痕量元素含量

Content of metals, organic compounds and other trace elements.

$\mathrm{pH}$ 值、盐度值、溶氧量、有机质含量

$\mathrm{pH}$ value, salinity value, dissolved oxygen, and content of organic matter.

初级生产、净生态系统生产、增长率

Primary production, net ecosystem production, and growth rate.

氮磷循环、其他营养循环

Nitrogen and phosphorus cycle, and other nutrient cycle.

地表径流模式、地下径流模式、水动力学、盐分特征、蓄水量

Surface runoff model, underground runoff model, hydrodynamics, salt characteristics, and water storage capacity.

海峡或海岸线形特征、河漫滩分布区域及范围、水生栖息地特征

Channel or coast line features, the distribution area and range of flood plain, and aquatic habitat characteristics.

沉积物补给、沉积物运动、粒径分布特征、其他物质通量

Sediment supply, sediment movement, the distribution characteristics of particle size, and other material flux.

火灾、虫害、洪涝、病原体

Fire, insects, floods, and pathogens. 
发, 它在评价独立且较为复杂的生态系统完整性时 具有极大的灵活性 (Brooks，2004; Tiner，2004; USEPA，2006)。该评估框架分为三个级别, 即远程 型评价、快速型评价和密集型评价(表3)。Michael (2011)运用三级法评估框架来评价和监控国家公园 和野生动物保护区的生态系统完整性, 对恢复该保 护区的野生动物资源种群数量做出了重要贡献。美 国国家公园管理局(U. S. National Park Service, NPS) 以三级法评估框架为导向建立了生态系统完整性 评估框架的指标体系。

\subsection{1 远程型评价}

远程型评价属于成本比较低廉的一种评价方 式, 它适用于所有自然生态系统, 近年来被广泛运 用在国家公园和野生动物保护区的生态系统完整 性评价中(Brooks, 2004; Tiner, 2004; USEPA, 2006; Michael et al, 2011)。远程型评价通常用在实地考察 难度较大的保护区中，主要通过地理信息系统(GIS) 和遥感数据来获取生态系统类型空间分布信息并 评估大尺度区域的生态系统完整性(Mack，2006; USEPA, 2006; Faber-Langendoen et al, 2009a), 其评 价指标通常是从经过处理的卫星遥感影像中获取。
远程型评价通常采用景观条件模型 (Landscape Condition Model, LCM) 对景观完整性进行全面评价 (Comer \& Hak, 2009), 该模型类似于人类足迹模型 (Human Footprint Model, HFM) (Leu \& Knick, 2008)、人为压力模型(Anthropogenic Stress Model, ASM) (Danz et al, 2007) 以及景观开发强度指数 (Landscape Development Intensity Index, LDII) (Brown \& Vivas, 2005), 将统一空间分辨率的土地 利用图层(道路、土地覆被、大坝、矿山等)整合在 一起作为压力指标的数据来源。由于不同压力指标 对生态系统完整性具有不同程度的响应，进而基于 距离衰减函数来分析压力指标对生态系统完整性 的影响，并从中获取压力指标的压力值。从高分辨 率影像图中提取的数据精度极高, 而且比实地考察 收集的数据更全面，且因成本低廉而得以推广 (USEPA, 2006; Faber-Langendoen et al, 2009a)。美国 国家环境保护局已把远程型评价方法运用在国家 野生动物保护区生态系统完整性评价中。

\subsection{2 快速型评价}

快速型评价是一种基于实地考察的生态系统 完整性评价方法。它采用通用随机方格分层算法

表3 三级法评估框架各个级别之间的差异(Stevens \& Olsen, 1999; Blocksom et al, 2002; USEPA, 2006; Michael et al, 2011)

Table 3 Differences of each level of Three Level Approach to conduct ecosystem integrity assessment (Stevens \& Olsen, 1999; Blocksom et al, 2002; USEPA, 2006; Michael et al, 2011)

\begin{tabular}{llll}
\hline & 远程型评价 Remote assessment & 快速型评价 Rapid assessment & 密集型评价 Intensive assessment \\
\hline 方法 & 使用地理信息系统(GIS)和遥感数据 & 使用相对简单且容易获得的实地调研 & 使用相对详细且可量化的实地调研指标 \\
Method & $\begin{array}{l}\text { Using Geographical Information Sys- } \\
\text { tem (GIS) and the remote sensing }\end{array}$ & $\begin{array}{l}\text { Using relatively simple and easily ob- } \\
\text { tatar }\end{array}$ & $\begin{array}{l}\text { Using rey indicators } \\
\text { tained field survey indicators }\end{array}$
\end{tabular}

数据源

Data sources

指标

Indicators

功能 Function

\section{遥感影像}

Remote sensing data

景观指数、土地覆盖、土地利用变 化、路网密度、大坝数量及分布区 域、不透水面面积比例等。

Landscape index, land cover, land use of dams, distribution area of dams, invasion, forest surface condition, hydro- tion structure, hydrology, ratio of soil calcium area proportion of impervious surface, logy, soil, ditch, pollution source input, and aluminum, etc. etc.

识别优先保护区域、分析景观生态 类型目前状况和发展趋势、监控目 标生态系统的恢复等。

Identifying priority protection area, analyzing the current situation and development trend of landscape ecological type, monitoring the restoration of target ecosystem, etc.

实地调研指标

Field survey indicators 管理生态恢复项目的实施情况、为流域 系统完整性评价的准确性、进一步完善生态 景观规划提供指导、为生态保护提供参 系统完整性评分报告、监控或管理生态恢复 考等。 项目的实施情况等。

Improving the ecosystem integrity score Detailed field measurement and statistical samreport, monitoring or managing the im- pling design can improve the accuracy of ecoplementation of ecological restoration system integrity evaluation. Improving the project, providing guidance for water- ecosystem integrity score report, monitoring or shed landscape planning, providing ref- managing the implementation situation of the erence for ecological conservation, etc. ecological restoration project, etc. 
(Generalized Random Tessellation Stratified, GRTS) 进行空间平衡抽样获取样点, 进而通过实地考察来 获取区域生态系统完整性评价指标(Stevens \& Olsen, 1999)。该评价方法中的指标获取相比其他评价 方法更直接、更迅速、更有效。快速型评价方法将 获取的评价指标以定量或半定量的形式组合在一 起, 然后通过判读各个指标的度量值来评价区域生 态系统的完整性。美国国家公园和野生动物保护区 大力推崇快速型评价法, 它可以用来识别目标区域 中的脆弱生态系统和生态敏感区, 这对于优先保护 区域的划分、保护地的恢复与重建有着现实意义。

\subsection{3 密集型评价}

密集型评价对评价指标的精度要求较高, 通常 要进行严格的实地采样来获取详细且精准的评价 指标并定量评价区域生态系统完整性(Blocksom et $\mathrm{al}, 2002)$ 。由于通过实地取样来获得植被、土壤、 水文、鸟类、鱼类、两栖类以及无脊椎动物等量化 指标需要花费更多的人力、物力, 因此密集型评价 方法相对其他方法而言成本最高, 但评估结果最为 准确, 对于监测生态系统动态意义重大(Rocchio \& Crawford, 2009)。该方法通常需要配合远程型评价 和快速型评价一起使用, 进行递进式评价。

三级法评估框架作为一套完整的生态系统完 整性评估框架, 每个级别都可以独立完成相应的评 价工作。由于评价对象、评价目的以及评价指标获 取的难易度存在差异, 不同研究选取不同的级别来 完成评价工作。在条件允许的情况下, 三个级别可 相结合进行递进式评价, 前提是三个级别上评价的 指标体系或概念模型的选择标准是一致的。

\section{4 生态系统完整性评估框架}

世界上许多科研机构参与了生态系统完整性 评估框架的研发和改进工作, 包括大自然保护协会 (The Nature Conservancy)、公益自然(NatureServe)、 美国国家公园管理局(U. S. National Park Service)以 及华盛顿州自然资源部(Washington State Department of Natural Resources) (Faber-Langendoen et al, 2009a, b)。生态系统完整性评估框架结合了大自然 保护协会和公益自然的生态理念和保护经验, 其目 的是加强生物多样性保护、提高生物资源管理效率 (Brown \& Williams, 2016)。它属于多指标评价方法, 通过记录生物和非生物的退化过程来反映生态系 统是否完整, 利用生态系统完整性指标记分矩阵来
反映评价结果，每个指标得分通过计算测量值和参 考值得到(Michael et al, 2011)。生态系统完整性评估 框架相比其他评价方法更为灵活，通过调整指标的 组合可以完成多种生态系统的完整性评估，同时， 它结合了三级法评估框架(表3)来完成多尺度生态 系统完整性的评估。生态系统完整性评估框架在指 标选取方面也有所突破，不仅考虑了影响当前生态 系统完整性的指标, 还考虑了影响未来生态系统完 整性的指标，如森林病原体和土壤原生病原体。森 林病原体(包括本地病原体和外来病原体)强烈影响 森林结构, 甚至导致森林死亡, 进而增加森林火灾 隐患; 土壤原生病原体是森林植被和生态系统的自 然干扰因素之一, 它可引起植物枯萎、死亡。

生态系统完整性评估框架被广泛运用在国家 公园和野生动植物保护区的生态系统完整性监测 和评价中。美国堪萨斯大学(Kansas University)运用 生态系统完整性评估框架对堪萨斯州的Wolf Creek 流域的生物状况、水质进行了全面评价(Liechti \& Dzialowski, 2003); 纽约州立环境科学与森林学院 把生态系统完整性评估框架运用在了国家公园森 林生态系统监测和完整性评价中(Tierney et al, 2009); 华盛顿州鱼类和野生动物部运用生态系统 完整性评估框架对华盛顿野生动植物分布区进行 了生态系统监控和评价, 并运用该框架的计分统计 法评价了落基山脉亚高山林地生态系统完整性(附 录1); 加拿大国家公园管理局运用生态系统完整性 评估框架来评估一个区域是否可以建立国家公园 (Parks Canada, 2000)。生态系统完整性评估框架吸 取了生物完整性指数评价体系和三级法评估框架 的优点, 扩充了评价指标, 优化了计分统计法, 是 目前最为成熟的评价方法之一。

\section{结语}

国家公园的生态系统完整性是国家公园的核 心价值和管理目标，其整体性评价可为管理部门制 定保护策略和调整管理模式提供依据(Elisa et al, 2016)。经过多年研究，国家公园生态系统完整性评 价的理论基础得到了深入，评价体系也逐渐完善， 一些评估框架和体系在实际运用中也真实有效。现 有国家公园生态系统完整性评价体系具备评价方 式灵活、数据收集便利、可重复性强和易操作等特 点, 因此被很多国家运用到保护地管理和规划中, 
证明了这些方法是评价敏感的自然生态系统受人 类活动干扰影响程度的重要工具(Schweiger et al, 2016)。这些方法弥补了以往国家公园生态系统完整 性研究的空缺, 提升了国家公园管理的有效性和布 局的合理性, 为保护大尺度的生态过程、相关物种 以及生态系统特性做出了贡献。

目前, 我国国家公园体制经过试点探索已积累 了一些宝贵经验，同时也遇到了一些亟待解决的问 题，例如：(1)国家公园范围划定不合理：部分区域 属于自然生态系统主体却没有被划入到保护地范 围之内, 而一些并不属于自然生态系统主体的区域 却被划入其中, 使得生态系统完整性没有得到科学 的保护; (2)优先保护区域不明确: 部分国家公园体 制试点整合了周边多个保护地, 使原先互不相连的 保护地连成一片, 但目前保护工作中仍参照以前的 功能区划进行管理, 没有对整合后的保护地进行生 态系统完整性评价以及重新划分功能区。

国家公园生态系统完整性评价方法有助于解 决我国国家公园体制试点中遇到的一些问题，诸如: (1)科学界定国家公园范围, 估算不同生态区域的国 家公园面积; (2)识别和选取国家公园优先保护区域; (3)科学划定国家公园功能分区; (4)评价国家公园生 境质量, 监测生物资源动态; (5)判定国家公园受环 境变化和人为干扰的影响是否仍具有代表性等。但 由于国家公园涉及的生态系统本身极其复杂, 加之 生态系统完整性内涵比较丰富, 因此国家公园生态 系统完整性评价的工作仍然具有极大的挑战性。

为了发挥国家公园生态系统完整性评价方法 在我国国家公园管理中的优势并提升评价方法的 科学性, 建议我国科研人员和管理决策者：(1)在运 用生态系统完整性评价方法来规划和管理国家公 园时需考虑生态系统和生态过程的完整性, 避免单 纯使用行政边界来划分国家公园范围, 必要时可使 用动态边界; (2)在对国家公园水生生态系统完整性 评价时, 采样点应尽量覆盖整个流域; (3)加强外来 入侵物种与生态环境关系的研究, 继续寻找能够反 映生态系统完整性状态和变化趋势的新的指示物 种; (4)在建立国家公园生态系统完整性评价指标时 可加入真菌、细菌等微生物指标; (5)在建立评价体 系时可从社会经济可持续发展与人类健康等方面 来建立新的评价指标, 如自然资源利用方式与保护 的一致性、传统文化资源保护水平、社区居民保护
意愿以及社区生态补偿程度等。

\section{参考文献}

Abebe FB, Bekele SE (2018) Challenges to national park conservation and management in Ethiopia. Journal of Agricultural Science, 10, 52-62.

Baron EAF (2003) Evaluating a Benthic Index of Biotic Integrity (B-IBI) to Measure Ecological Integrity in Pacific Rim National Park Reserve of Canada. Simon Fraser University Press, Burnaby, Canada.

Blocksom KA, Kurtenbach JP, Klemm DJ, Fulk FA, Cormier SM (2002) Development and evaluation of the Lake Macroinvertebrate Integrity Index (LMII) for New Jersey lakes and reservoirs. Environmental Monitoring and Assessment, 77, 311-333.

Brewer JS, Menzel T (2009) A method for evaluating outcomes of restoration when no reference sites exist. Restoration Ecology, 17, 4-11.

Brooks RP, Wardrop DH, Bishop JA (2004) Assessing wetland condition on a watershed basis in the mid-Atlantic region using synoptic land-cover maps. Environmental Monitoring and Assessment, 94, 9-22.

Brown ED, Williams BK (2016) Ecological integrity assessment as a metric of biodiversity: Are we measuring what we say we are? Biodiversity and Conservation, 25, 1011-1035.

Brown MT, Vivas MB (2005) Landscape development intensity index. Environmental Monitoring and Assessment, 101, 289-309.

Caniani D, Labella A, Lioi DS, Mancini IM, Masi S (2016) Habitat ecological integrity and environmental impact assessment of anthropic activities: A GIS-based fuzzy logic model for sites of high biodiversity conservation interest. Ecological Indicators, 67, 238-249.

Casatti L, Ferreira CP, Langeani F (2009) A fish-based biotic integrity index for assessment of lowland streams in southeastern Brazil. Hydrobiologia, 623, 173-189.

Chin ATM, Tozer DC, Fraser GS (2014) Hydrology influences generalist-specialist bird-based indices of biotic integrity in Great Lakes coastal wetlands. Journal of Great Lakes Research, 40, 281-287.

Comer PJ, Hak J (2009) NatureServe Landscape Condition Model. Internal documentation for NatureServe Vista Decision Support Software Engineering. NatureServe, Colorado, USA.

Danz NP, Neimi GJ, Regal RR, Hollenhorst TP, Johnson LB, Hanowski JM, Axler RP, Ciborowski JJH, Hrabik T, Brady VJ, Kelly JR, Morrice JA, Brazner JC, Howe RW, Johnston CA, Host GE (2007) Integrated measures of anthropogenic stress in the U. S. Great Lakes Basin. Environmental Management, 39, 631-647.

Dudley N, Hockings M, Stolton S (1999) Measuring the Effectiveness of Protected Areas Management. Earthscan Publi- 
cations, London.

Elisa M, Shultz S, White K (2016) Impact of surface water extraction on water quality and ecological integrity in Arusha National Park, Tanzania. African Journal of Ecology, 54, 174-182.

Faber-Langendoen D, Kudray G, Nordman C, Sneddon L, Vance L, Byers E, Rocchio J, Gawler S, Kittel G, Menard S, Comer P, Muldavin E, Schafale M, Foti T, Josse C, Christy $\mathrm{J}$ (2009a) Assessing the condition of ecosystems to guide conservation and management: An overview of NatureServe's ecological integrity assessment methods. NatureServe, Virginia, USA.

Faber-Langendoen D, Lyons R, Comer P (2009b) Developing Options for Establishing Reference Conditions for Wetlands Across the Lower 48 States: A Report to the U. S. Environmental Protection Agency. NatureServe, Virginia, USA.

Fairweather PG (1991) Statistical power and design requirements for environmental monitoring. Marine and Freshwater Research, 42, 555-567.

Franklin JF, Spies TA, Pelt RV, Carey AB, Thornburgh DA, Berg DR (2002) Disturbances and structural development of natural forest ecosystems with silvicultural implications, using Douglas-fir forests as an example. Forest Ecology and Management, 155, 399-423.

Gaston KJ, Charman K, Jackson SF, Armsworth PR, Bonn A, Briers RA (2006) The ecological effectiveness of protected areas: The United Kingdom. Biological Conservation, 132, 76-87.

Harwell MA, Myers V, Young T, Bartuska A, Gassman N, Gentile JH, Harwell CC, Appelbaum S, Barko J, Causey B, Johnson C, McLean A, Smola R, Templet P, Tosini S (1999) A framework for an ecosystem integrity report card. BioScience, 49, 543-556.

Hockings M, Stolton S, Leverington F, Dudley N, Courrau J (2000) Assessing effectiveness - A framework for assessing management effectiveness of protected areas. Archivos de Pediatría del Uruguay, 71, 5-9.

IUCN (International Union for Conservation of Nature) (1993) IUCN Category. II. http://www.biodiversitya-z.org/content/ iucn-category-ii-national-park (accessed on 2018-02-10)

Kane DD, Gordon SI, Munawar M, Charlton MN, Culver DA (2009) The planktonic index of biotic integrity (P-IBI): An approach for assessing lake ecosystem health. Ecological Indicators, 9, 1234-1247.

Karr JR (1981) Assessment of biotic integrity using fish communities. Fisheries, 6, 21-27.

Karr JR, Dudley DR (1981) Ecological perspective on water quality goals. Environmental Management, 5, 55-68.

Ladin ZS, Higgins C, Schmit JP, Sanders G, Johnson MJ, Weed AS (2016) Using regional bird community dynamics to evaluate ecological integrity within national parks. Ecosphere, 7, e01464.

Lawrence JE, Deitch MJ, Resh VH (2011) Effects of vineyard coverage and extent on benthic macroinvertebrates in streams of Northern California. Annales de Limnologie-In ternational Journal of Limnology, 47, 347-354.

Leopold A (1949) Sand County Almanac and Sketches Here and There. Oxford University Press, New York.

Leu M, Knick HST (2008) The Human Footprint in the West: A Large-Scale Analysis of Anthropogenic Impacts. Ecological Applications, 18, 1119-1139.

Li T, Huang X, Jiang X, Wang X (2015) Assessment of ecosystem health of the Yellow River with fish index of biotic integrity. Hydrobiologia, 412, 1-13.

Liechti P, Dzialowski A (2003) Final Assessment of the Ecological Integrity of Wolf Creek. University of Kansas, Kansas, USA.

Lunde KB, Resh VH (2012) Development and validation of a macroinvertebrate index of biotic integrity (IBI) for assessing urban impacts to Northern California freshwater wetlands. Environmental Monitoring and Assessment, 184, 3653-3674.

Mack JJ (2006) Landscape as a predictor of wetland condition: An evaluation of the Landscape Development Index (LDI) with a large reference wetland dataset from Ohio. Environmental Monitoring and Assessment, 120, 221-241.

Mahan G, Young JA, Miller BJ, Saunders MC (2015) Using ecological indicators and a decision support system for integrated ecological assessment at two national park units in the mid-Atlantic region, USA. Environmental Management, 5, 508-522.

Medeiros HR, Torezan JM (2013) Evaluating the ecological integrity of Atlantic forest remnants by using rapid ecological assessment. Environmental Monitoring and Assessment, 18, 4373-4382.

Michael A, Schroeder RC, Crawford FJ, Rocchio DJ (2011) Ecological Integrity Assessments: Monitoring and Evaluation of Wildlife Areas in Washington. Washington Department of Fish and Wildlife, Washington, USA.

Müller F (1998) Gradients in ecological systems. Ecological Modelling, 108, 3-21.

Murtaugh PA (1996) The statistical evaluation of ecological indicators. Ecological Applications, 6, 132-139.

Noss RF (1990) Indicators for monitoring biodiversity: A hierarchical approach. Conservation Biology, 4, 355-364.

Parks Canada Agency (2005) Monitoring and Reporting Ecological Integrity in Canada's National Parks, Guiding Principles, Vol. 1. Parks Canada Agency, Quebec, Canada.

Parrish JD, Braun DP, Unnasch RS (2003) Are we conserving what we say we are? Measuring ecological integrity within protected areas. BioScience, 5, 851-860.

Peng YJ, Fan J, Xing SH, Cui GF (2018) Overview and classification outlook of natural protected areas in mainland China. Biodiversity Science, 26, 315-325. (in Chinese with English abstract) [彭杨靖, 樊简, 邢韶华, 崔国发 (2018) 中国大陆自然保护地概况及分类体系构想. 生物多样性, 
26, 315-325.]

Raab D, Bayley SE (2012) A vegetation-based Index of Biotic Integrity to assess marsh reclamation success in the Alberta oil sands, Canada. Ecological Indicators, 15, 43-51.

Raburu PO, Masese FO, Mulanda CA (2009) Macroinvertebrate Index of Biotic Integrity (M-IBI) for monitoring rivers in the upper catchment of Lake Victoria Basin, Kenya. Aquatic Ecosystem Health and Management, 12, 197-205.

Rocchio FJ, Crawford RC (2009) Monitoring Desired Ecological Conditions on Washington State Wildlife Areas Using an Ecological Integrity Assessment Framework. Washington Natural Heritage Program, Washington Department of Natural Resources Olympia, Washington.

Rodrigues ASL, Andelman SJ, Bakarr MI, Boitani L, Brooks TM, Cowling RM (2004) Effectiveness of the global protected area network in representing species diversity. Nature, 428, 640-643.

Salafsky N, Margoluis R, Redford KH, Robinson JG (2002) Improving the practice of conservation: A conceptual framework and research agenda for conservation science. Conservation Biology, 16, 1469-1479.

Schroeder MA, Gorrell J, Haegen MV, Anthony J, Duff A, Foisy J (2017) Ecological Integrity Monitoring of Wildlife Areas in Washington State: Pilot Study Report for the 2011-2013 Biennium. Lands Division, Wildlife Program. Washington Department of Fish and Wildlife, Washington.

Schweiger EW, Grace JB, Cooper D, Bobowski B, Britten M (2016) Using structural equation modeling to link human activities to wetland ecological integrity. Ecosphere, 7, $1-30$.

Scott JM, Davis FW, Mcghie RG, Wright RG, Groves C, Estes J (2001) Nature Reserves: Do they capture the full range of America's biological diversity? Ecological Applications, 11, 999-1007.

Stapanian MA, Mack J, Adams JV, Gara B, Micacchion M (2013) Disturbance metrics predict a wetland vegetation index of biotic integrity. Ecological Indicators, 24, 120-126.

Stevens L, Olsen AR (1999) Spatially restricted surveys over time for aquatic resources. Journal of Agricultural, Biological, and Environmental Statistics, 4, 415-428.

Stolton S (2004) Management effectiveness: Assessing management of protected areas. Journal of Environmental Policy and Planning, 6, 157-174.
Tan X, Ma P, Bunn SE, Zhang Q (2015) Development of a Benthic Diatom Index of Biotic Integrity (BD-IBI) for ecosystem health assessment of human dominant subtropical rivers, China. Journal of Environmental Management, 151, 286-294.

Tang FL (2017) National Park: Theory and Practice. China Forestry Publishing House, Beijing. (in Chinese) [唐芳林 (2017) 国家公园理论与实践. 中国林业出版社, 北京.]

Tierney GL, Faber-Langendoen D, Mitchell BR, Shriver WG, Gibbs JP (2009) Monitoring and evaluating the ecological integrity of forest ecosystems. Frontiers in Ecology and the Environment, 7, 308-316.

Timko J, Innes JL (2009) Evaluating ecological integrity in national parks: Case studies from Canada and South Africa. Biological Conservation, 142, 676-688.

Timko J, Satterfield T (2008) Criteria and indicators for evaluating social equity and ecological integrity in national parks and protected areas. Natural Areas Journal, 28, 307-319.

Tiner RW (2004) Remotely-sensed indicators for monitoring the general condition. Ecological Indicators, 4, 227-243.

Troy R, Yolanda F (2017) Ten years of monitoring air quality and ecological integrity using field-identifiable lichens at Kejimkujik National Park and National Historic Site in Nova Scotia, Canada. Ecological Indicators, 81, 214-221.

USEPA (U. S. Environmental Protection Agency) (2006) Application of Elements of a State Water Monitoring and Assessment Program for Wetlands. U. S. Environmental Protection Agency, Washington, DC.

Woodley S (1993) Monitoring and Measuring Ecosystem Integrity in Canadian National Parks. St. Lucie Press, Ottawa, Canada.

Young TF, Sanzone S (2002) A Framework for Assessing and Reporting on Ecological Condition. Prepared by the Ecological Reporting Panel, Ecological Processes and Effects Committee. USEPA Science Advisory Board, Washington, DC.

Zhang MY, Wang KL, He P (2005) Advances in assessment of ecosystem integrity. Tropical Geography, 25, 10-13. (in Chinese with English abstract) [张明阳, 王克林, 何萍 (2005) 生态系统完整性评价研究进展. 热带地理, 25, 10-13.]

(责任编委: 李俊生 责任编辑: 时意专)

\section{附录 Supplementary Material}

附录1 林地生态系统完整性评价计分卡(Michael et al, 2011)

Appendix 1 Forest and woodland Ecosystem Integrity Assessment scorecard (Michael et al, 2011)

http://www.biodiversity-science.net/fileup/PDF/2018-142-1.pdf 
代云川, 薛亚东, 张云毅, 李迪强. 国家公园生态系统完整性评价研究进展. 生物多样性, 2019, 27 (1): 104-113.

http://www.biodiversity-science.net/fileup/PDF/2018142

附录1 林地生态系统完整性评价计分卡(Michael et al, 2011)

Appendix 1 Forest and woodland Ecosystem Integrity Assessment scorecard (Michael et al, 2011)

\begin{tabular}{|c|c|c|c|c|c|}
\hline \multirow{2}{*}{$\begin{array}{l}\text { 指标 } \\
\text { Indicator }\end{array}$} & \multirow{2}{*}{$\begin{array}{l}\text { 理由 } \\
\text { Justification }\end{array}$} & \multicolumn{4}{|c|}{ 预估完整性等级 Estimated integrity rank } \\
\hline & & $\begin{array}{l}\text { A (极好) } \\
\text { A (Excellent) }\end{array}$ & $\begin{array}{l}\text { B (好) } \\
\text { B (Good) }\end{array}$ & $\begin{array}{l}\text { C (一般) } \\
\text { C (Fair) }\end{array}$ & $\begin{array}{l}\mathrm{D} \text { (差) } \\
\mathrm{D} \text { (Poor) }\end{array}$ \\
\hline \multicolumn{6}{|c|}{ 关键生态属性: 景观 Key ecological attribute: Landscape } \\
\hline $\begin{array}{l}\text { 边缘长度 } \\
\text { Edge length }\end{array}$ & $\begin{array}{l}\text { 边缘完整性是生物存活 } \\
\text { 的一个重要指标。 } \\
\text { Edge integrity is an } \\
\text { important indicator of } \\
\text { biological survival. }\end{array}$ & $\begin{array}{l}\geq 75 \% \text { 的边缘为自然群 } \\
\text { 落。 } \\
\geq 75 \% \text { of edge occupied } \\
\text { by natural communities. }\end{array}$ & $\begin{array}{l}50-75 \% \text { 的边缘为自然 } \\
\text { 群落。 } \\
50-75 \% \text { of edge } \\
\text { occupied by natural } \\
\text { communities. }\end{array}$ & $\begin{array}{l}25-50 \% \text { 的边缘为 } \\
\text { 自然群落。 } \\
25-50 \% \text { of edge } \\
\text { occupied by natural } \\
\text { communities. }\end{array}$ & $\begin{array}{l}<25 \% \text { 的边缘为自然群 } \\
\text { 落。 } \\
<25 \% \text { of edge occupied } \\
\text { by natural communities. }\end{array}$ \\
\hline $\begin{array}{l}\text { 边缘宽度 } \\
\text { Edge width }\end{array}$ & & $\begin{array}{l}\text { 平均边缘宽度 } \geq 100 \mathrm{~m} \text { 。 } \\
\text { Average width of edge } \\
\geq 100 \mathrm{~m} .\end{array}$ & $\begin{array}{l}\text { 平均边缘宽度 } 75-100 \\
\mathrm{~m} \\
\text { Average width of edge } \\
75-100 \mathrm{~m} .\end{array}$ & $\begin{array}{l}\text { 平均边缘宽25-75 } \\
\text { m。 } \\
\text { Average width of } \\
\text { edge } 25-75 \mathrm{~m} .\end{array}$ & $\begin{array}{l}\text { 平均边缘宽度 }<25 \mathrm{~m} \text { 。 } \\
\text { Average width of edge } \\
<25 \mathrm{~m} .\end{array}$ \\
\hline $\begin{array}{l}\text { 边缘状况 } \\
\text { Edge condition }\end{array}$ & & $\begin{array}{l}>95 \% \text { 的原生植被; } \\
<5 \% \text { 的非原生植被; 原 } \\
\text { 状土。 } \\
>95 \% \text { native vegetation } \\
\text { cover; }<5 \% \text { non-native } \\
\text { vegetation cover; } \\
\text { undisturbed soils. }\end{array}$ & $\begin{array}{l}75-95 \% \text { 的原生植被; } \\
5-25 \% \text { 的非原生植被; } \\
\text { 土壤完好或中度受损。 } \\
75-95 \% \text { native } \\
\text { vegetation cover; } \\
\text { 5-25\% non-native } \\
\text { vegetation cover; intact } \\
\text { or moderately disrupted } \\
\text { soils. }\end{array}$ & $\begin{array}{l}25-50 \% \text { 的非原生 } \\
\text { 植被; 土壤中度或 } \\
\text { 严重受损。 } \\
25-50 \% \text { non-native } \\
\text { vegetation cover; } \\
\text { moderate or } \\
\text { extensive soil } \\
\text { disruption. }\end{array}$ & $\begin{array}{l}>50 \% \text { 的非原生植被; } \\
\text { 贫癒土地; 土壤高度受 } \\
\text { 损或是以其他形式破 } \\
\text { 坏。 } \\
>50 \% \text { non-native } \\
\text { vegetation cover; barren } \\
\text { land; soil is highly } \\
\text { damaged or other forms } \\
\text { of damage. }\end{array}$ \\
\hline $\begin{array}{l}\text { 连通性 } \\
\text { Connectivity }\end{array}$ & $\begin{array}{l}\text { 自然或半自然植被的廊 } \\
\text { 道能提高连通性。 } \\
\text { Corridor of natural or } \\
\text { semi-natural vegetation } \\
\text { can improve connectivity. }\end{array}$ & $\begin{array}{l}90-100 \% \text { 的自然栖息 } \\
\text { 地; 连通性极高 } \\
90-100 \% \text { natural } \\
\text { habitat; connectivity } \\
\text { extremely high. }\end{array}$ & $\begin{array}{l}60-90 \% \text { 的自然栖息地; } \\
\text { 连通性较高。 } \\
60-90 \% \text { natural habitat; } \\
\text { connectivity relatively } \\
\text { high. }\end{array}$ & $\begin{array}{l}20-60 \% \text { 的自然栖 } \\
\text { 息地; 连通性低。 } \\
20-60 \% \text { natural } \\
\text { habitat; } \\
\text { connectivity low. }\end{array}$ & $\begin{array}{l}<20 \% \text { 自然栖息地; 无 } \\
\text { 连通性。 } \\
<20 \% \text { natural habitat; no } \\
\text { connectivity. }\end{array}$ \\
\hline $\begin{array}{l}\text { 景观状况 } \\
\text { Landscape condition }\end{array}$ & $\begin{array}{l}\text { 土地利用类型和使用强 } \\
\text { 度影响生态系统完整 } \\
\text { 性。 } \\
\text { Land-use type and } \\
\text { intensity can affect } \\
\text { ecosystem integrity. }\end{array}$ & \multicolumn{2}{|c|}{$\begin{array}{l}\text { 景观模型指数 }>0.8 \text { 。 } \\
\text { Landscape model index }>0.8 \text {. }\end{array}$} & $\begin{array}{l}\text { 景观模型指数在 } \\
0.65-0.8 \text { 之间。 } \\
\text { Landscape } \\
\text { model index is } \\
\text { between } 0.65-0.8 \text {. }\end{array}$ & $\begin{array}{l}\text { 景观模型指数 }<0.65 \text { 。 } \\
\text { Landscape model index } \\
<0.65 \text {. }\end{array}$ \\
\hline $\begin{array}{l}\text { 相对斑块大小 } \\
\text { Relative patch size }\end{array}$ & $\begin{array}{l}\text { 压力源引起斑块比例的 } \\
\text { 下降, 其结果直接影响 } \\
\text { 生态系统完整性。 } \\
\text { Patch proportion } \\
\text { lost due to stressors, } \\
\text { which directly affects } \\
\text { ecosystem integrity. }\end{array}$ & $\begin{array}{l}\text { 轻微下降; } \geq 95 \% \text { 的自 } \\
\text { 然斑块面积。 } \\
\text { Slightly decrease; } \\
\text { natural patch area } \\
\geq 95 \% .\end{array}$ & $\begin{array}{l}\text { 中度下降; 80-95\%的 } \\
\text { 自然斑块面积。 } \\
\text { Moderately decrease; } \\
\text { natural patch area is } \\
\text { between } 80-95 \% .\end{array}$ & $\begin{array}{l}\text { 持续下降; } 50- \\
80 \% \text { 的自然斑块面 } \\
\text { 积。 } \\
\text { Continuously } \\
\text { decrease; natural } \\
\text { patch area is } \\
\text { between } 50-80 \% .\end{array}$ & $\begin{array}{l}\text { 严重下降; }<50 \% \text { 的自 } \\
\text { 然斑块面积。 } \\
\text { Severely decrease; } \\
\text { natural patch area } \\
<50 \% \text {. }\end{array}$ \\
\hline $\begin{array}{l}\text { 绝对斑块大小 } \\
\text { Absolute patch size }\end{array}$ & $\begin{array}{l}\text { 对缓冲区影响极大。 } \\
\text { It has a huge impact on } \\
\text { buffers. }\end{array}$ & $>10,000$ ha. & $1,000-10,000$ ha. & $100-1,000$ ha. & $<100$ ha. \\
\hline \multicolumn{6}{|c|}{ 关键生态属性: 植被 Key ecological attribute: Vegetation } \\
\hline $\begin{array}{l}\text { 原生物种覆盖度 } \\
\text { Cover of native } \\
\text { species }\end{array}$ & $\begin{array}{l}\text { 由于人类影响, 非原生 } \\
\text { 物种增加。 } \\
\text { Non-natives increase } \\
\text { with human impacts. }\end{array}$ & $\begin{array}{l}\text { 原生植被覆盖度 } \\
\geq 95 \% \text { 。 } \\
\text { Cover of native species } \\
\geq 95 \% \text {. }\end{array}$ & $\begin{array}{l}\text { 原生植被覆盖度 } 80- \\
95 \% \text { 。 } \\
\text { Cover of native species } \\
\text { occupied } 80-95 \% .\end{array}$ & $\begin{array}{l}\text { 原生植被覆盖度 } \\
50-80 \% \text { 。 } \\
\text { Cover of native } \\
\text { species occupied } \\
50-80 \% .\end{array}$ & $\begin{array}{l}\text { 原生植被覆盖度 } \\
<50 \% \text { 。 } \\
\text { Cover of native species } \\
<50 \% \text {. }\end{array}$ \\
\hline $\begin{array}{l}\text { 物种组成 } \\
\text { Composition }\end{array}$ & $\begin{array}{l}\text { 当暴露在压力源之下, } \\
\text { 原生物种组成发生改 } \\
\text { 变。 } \\
\text { Composition of } \\
\text { native species can } \\
\text { shift when exposed to } \\
\text { stressors. }\end{array}$ & $\begin{array}{l}\text { 多样性/丰富度在参考 } \\
\text { 值范围内或接近参考 } \\
\text { 值; 存在一些指示物。 } \\
\text { Diversity/richness } \\
\text { within or near the } \\
\text { reference standards; } \\
\text { indicator species } \\
\text { present. }\end{array}$ & $\begin{array}{l}\text { 多样性/丰富度接近参 } \\
\text { 考值;人类活动对原 } \\
\text { 生种构成威胁; 一些 } \\
\text { 指示物种消失。 } \\
\text { Diversity/Richness near } \\
\text { the reference standards; } \\
\text { human activities pose a } \\
\text { threat to native species; } \\
\text { some indicator species } \\
\text { absent. }\end{array}$ & $\begin{array}{l}\text { 多样性/丰富度不 } \\
\text { 同于参考值; 很多 } \\
\text { 指示物种消失。 } \\
\text { Diversity/richness } \\
\text { are different from } \\
\text { the reference } \\
\text { standards; many } \\
\text { indicator species } \\
\text { absent. }\end{array}$ & $\begin{array}{l}\text { 从参考值来看, 植被发 } \\
\text { 生严重改变; 优势种被 } \\
\text { 其他物种代替; 大量的 } \\
\text { 指示物种消失。 } \\
\text { Vegetation severely } \\
\text { altered from reference } \\
\text { standards; dominant } \\
\text { species were replaced } \\
\text { by other species; most } \\
\text { indicator species absent. }\end{array}$ \\
\hline
\end{tabular}




\begin{tabular}{|c|c|c|c|c|c|}
\hline \multirow{2}{*}{$\begin{array}{l}\text { 指标 } \\
\text { Indicator }\end{array}$} & \multirow{2}{*}{$\begin{array}{l}\text { 理由 } \\
\text { Justification }\end{array}$} & \multicolumn{4}{|c|}{ 预估完整性等级 Estimated integrity rank } \\
\hline & & $\begin{array}{l}\text { A (极好) } \\
\text { A (Excellent) }\end{array}$ & $\begin{array}{l}\text { B (好) } \\
\text { B (Good) }\end{array}$ & $\begin{array}{l}\text { C (一般) } \\
\text { C (Fair) }\end{array}$ & $\begin{array}{l}\text { D (差) } \\
\text { D (Poor) }\end{array}$ \\
\hline $\begin{array}{l}\text { 郁闭度 } \\
\text { Canopy density }\end{array}$ & $\begin{array}{l}\text { 多层耐阴和非耐阴性 } \\
\text { 树种。 } \\
\text { Multilayered shade } \\
\text { tolerant and } \\
\text { intolerant trees. }\end{array}$ & $\begin{array}{l}\text { 大量古树没受破坏; } \\
\text { 树木残桩极少; 部分 } \\
\text { 大树的树龄> } 150 \text { 年; } \\
\text { 每公顷至少有 } 25 \text { 棵古 } \\
\text { 树(胸径大于 } 38 \mathrm{~cm}) \text { 。 } \\
\text { Majority of old trees } \\
\text { were not destroyed; } \\
\text { only few stumps; some } \\
\text { old trees }>150 \text { years } \\
\text { old; > } 25 \text { old trees/ha } \\
\text { (>38 cm DBH). }\end{array}$ & $\begin{array}{l}10-30 \% \text { 的古树被砍伐; } \\
\text { 每公顷有 } 10-25 \text { 棵古树 } \\
\text { (胸径大于 } 38 \mathrm{~cm} \text { )。 } \\
10-30 \% \text { old trees were } \\
\text { destroyed; } 10-25 \text { old } \\
\text { trees } / \text { ha }(>38 \mathrm{~cm} \\
\text { DBH). }\end{array}$ & $\begin{array}{l}\text { 超过 } 50 \% \text { 的古树被 } \\
\text { 砍伐; 每公顷有 } 5- \\
10 \text { 棵古树(胸径大 } \\
\text { 于 } 38 \mathrm{~cm}) \text { 。 } \\
>50 \% \text { of old trees } \\
\text { were destroyed; } 5- \\
10 \text { old trees } / \mathrm{ha} \\
\text { (>38 cm DBH). }\end{array}$ & $\begin{array}{l}\text { 几乎所有古树遭到破 } \\
\text { 坏; 每公顷不超过 } 5 \text { 棵 } \\
\text { 古树 }(\text { 胸径大于 } 38 \mathrm{~cm}) \text { 。 } \\
\text { Almost all the old trees } \\
\text { were destroyed; }<5 \text { old } \\
\text { trees } / \text { ha ( }>38 \mathrm{~cm} \mathrm{DBH}) .\end{array}$ \\
\hline $\begin{array}{l}\text { 粗木质残体 } \\
\text { Coarse woody debris }\end{array}$ & $\begin{array}{l}\text { 粗木质残体是评价潜 } \\
\text { 在火灾的重要指标。 } \\
\text { Coarse woody debris } \\
\text { is an important index to } \\
\text { evaluate potential fire. }\end{array}$ & $\begin{array}{l}\text { 在腐朽过程中随时间 } \\
\text { 的推移有很大的变化。 } \\
\text { Wide variety of downed } \\
\text { log sizes with large } \\
\text { variation in stages of } \\
\text { decay. }\end{array}$ & $\begin{array}{l}\text { 在腐朽过程中随时间的 } \\
\text { Wide variety of down } \\
\text { unobvious variation in sta }\end{array}$ & $\begin{array}{l}\text { 推移变化不明显。 } \\
\text { ned log sizes with } \\
\text { ages of decay. }\end{array}$ & $\begin{array}{l}\text { 在腐朽过程中随时间 } \\
\text { 的推移变化甚微。 } \\
\text { Wide variety of downed } \\
\text { log sizes with a little } \\
\text { variation in stages of } \\
\text { decay. }\end{array}$ \\
\hline \multicolumn{6}{|c|}{ 关键生态属性：理化性质 Key ecological attribute: Physicochemical } \\
\hline $\begin{array}{l}\text { 土壤表层状况 } \\
\text { Soil surface } \\
\text { condition }\end{array}$ & $\begin{array}{l}\text { 干扰引起土壤侵蚀和 } \\
\text { 压实, 从而影响生态过 } \\
\text { 程。 } \\
\text { Disturbance can } \\
\text { result in erosion and } \\
\text { compaction, thereby } \\
\text { affecting ecological } \\
\text { processes. }\end{array}$ & $\begin{array}{l}\text { 土壤干扰等级为 } 0 \text { : 没 } \\
\text { 有车轮压痕、土壤干 } \\
\text { 扰、压实以及侵蚀的证 } \\
\text { 据。 } \\
\text { Soil disturbance class is } \\
0: \text { No evidence of } \\
\text { wheel tracks, soil } \\
\text { disturbance, } \\
\text { compaction, and } \\
\text { erosion. }\end{array}$ & $\begin{array}{l}\text { 土壤干扰等级为 } 1 \text { : 车 } \\
\text { 轮压痕、土壤干扰、土 } \\
\text { 壤压实以及土壤侵蚀 } \\
\text { 的证据不明显。 } \\
\text { Soil disturbance class is } \\
\text { 1: Unobvious evidence } \\
\text { of wheel tracks, soil } \\
\text { disturbance, } \\
\text { compaction, and } \\
\text { erosion. }\end{array}$ & $\begin{array}{l}\text { 土壤干扰等级为 } 2: \\
\text { 车轮压痕、土壤干 } \\
\text { 扰、土壤压实以及 } \\
\text { 土壤侵蚀的证据 } \\
\text { 明显。 } \\
\text { Soil disturbance } \\
\text { class is 2: Obvious } \\
\text { evidence of wheel } \\
\text { tracks, soil } \\
\text { disturbance, } \\
\text { compaction, and } \\
\text { erosion. }\end{array}$ & $\begin{array}{l}\text { 土壤干扰等级为 } 3: \text { 车 } \\
\text { 轮压痕、土壤干扰、土 } \\
\text { 壤压实以及土壤侵蚀 } \\
\text { 的证据很明显。 } \\
\text { Soil disturbance class is } \\
\text { 2: Very obvious } \\
\text { evidence of wheel } \\
\text { tracks, soil disturbance, } \\
\text { compaction, and } \\
\text { erosion. }\end{array}$ \\
\hline \multicolumn{6}{|c|}{ 关键生态属性：自然干扰机制 Key ecological attribute: Natural disturbance regimes } \\
\hline $\begin{array}{l}\text { 森林病原体 } \\
\text { Forest pathogens }\end{array}$ & $\begin{array}{l}\text { 病原体是树木死亡的根 } \\
\text { 源, 进而影响森林结构, } \\
\text { 诱发火灾。 } \\
\text { Pathogens are the root } \\
\text { cause of tree death, which } \\
\text { affects forest structure } \\
\text { and induces fire. }\end{array}$ & $\begin{array}{l}\text { 病原体在正常变异范 } \\
\text { 围之内。 } \\
\text { Pathogens within } \\
\text { natural range of } \\
\text { variability. }\end{array}$ & $\begin{array}{l}\text { 本地病原体影响森林 } \\
\text { 结构。 } \\
\text { Native pathogens affect } \\
\text { forest structure. }\end{array}$ & $\begin{array}{l}\text { 外来病原体和本 } \\
\text { 地病原体影响森 } \\
\text { 林结构。 } \\
\text { Exotic and native } \\
\text { pathogens affect } \\
\text { forest structure. }\end{array}$ & $\begin{array}{l}\text { 外来病原体和本地病 } \\
\text { 原体强烈影响森林结 } \\
\text { 构。 } \\
\text { Exotic and native } \\
\text { pathogens significantly } \\
\text { affect forest structure. }\end{array}$ \\
\hline $\begin{array}{l}\text { 火烧等级 } \\
\text { Fire class }\end{array}$ & $\begin{array}{l}\text { 高强度火烧在保持生态 } \\
\text { 系统完整性中起着重要 } \\
\text { 作用。 } \\
\text { High severity fire is } \\
\text { vital for maintaining } \\
\text { ecosystem integrity. }\end{array}$ & $\begin{array}{l}\text { 火烧等级1: 不脱离 } \\
\text { 历史火烧管控制度。 } \\
\text { Fire class } 1: \text { No } \\
\text { departure from } \\
\text { historic fire regime. }\end{array}$ & $\begin{array}{l}\text { 火烧等级2: 轻度脱离历 } \\
\text { Fire class 2: Slightly depa } \\
\text { fire regime. }\end{array}$ & $\begin{array}{l}\text { 万史火烧管控制度。 } \\
\text { arture from historic }\end{array}$ & $\begin{array}{l}\text { 火烧等级3: 严重脱离 } \\
\text { 历史火烧管控制度; 存 } \\
\text { 在灭火证据。 } \\
\text { Fire class 3: Seriously } \\
\text { departure from historic } \\
\text { fire regime; evidence of } \\
\text { fire suppression. }\end{array}$ \\
\hline
\end{tabular}

